\section{'To switch or not to switch': the missing piece in the puzzle of biosimilar literature?}

We read with great interest the paper from Glintborg and coauthors 'To switch or not to switch' reporting biosimilar etanercept switching in Denmark. ${ }^{1}$

In the Danish Biologic (DANBIO) cohort, patient treated with originator etanercept (Enbrel) were informed of a mandatory switch to SB4. However, the $25 \mathrm{mg}$ pen or a powder-based preparation of original etanercept $(\mathrm{OE})$ were still available. At 1 year after this decision, the authors reported that only $79 \%$ of patients had switched to SB4 and 21\% remained treated with the originator biologic.

In westernised countries, biologics therapies take a high toll on healthcare systems. With their 20\%-50\% lower costs, biosimilars' wide diffusion are therefore a necessity in order to provide sustainable healthcare to patients with chronic inflammatory rheumatic diseases. While the use of biosimilar in patient initiating a treatment is a simple subject, switching from originator to biosimilar and the strategy to do it (shared decision vs mandatory switch) has been a hot topic of debate in the rheumatology community. ${ }^{2-5}$

Two strategies for the use of biosimilars can be differentiated in patients already treated with an originator: mandatory switch or physician-patient shared decision. Physician-patient shared decision has been favored by rheumatology scientific societies, by an international consensus group and by patients association. ${ }^{6-8}$ Indeed, real-life studies reporting the acceptance of the switch from OE to SB4 in case of shared decision together with an optimised communication strategy have reported acceptance rates of 92\%-99\%. ${ }^{9}{ }^{10}$ Outside an improved acceptance rate of physician-patient decision, there are reasonable evidence suggesting that forcing the switch on a patient is likely to increase the risk of nocebo effect, with negative effect on the patient and on physician-patient relationship (reviewed by Kravvaviti). ${ }^{11}$ This nocebo effect might, at best, mandate a reswitch to the originator, therefore, a failure of the switching strategy. In the worst case (if the originator is not available anymore), the patient will be switched to another (possibly originator) biologic, leading to an avoidable exhaustion of therapeutic options, a weakening of the patient-physician relationship and increased healthcare costs. Considering this body of evidence, we believe that Glintborg's study was the missing piece in the puzzle of the biosimilars literature, demonstrating that a mandatory switch is probably not the most efficient strategy for the wide diffusion of biosimilar in chronic rheumatic diseases and reinforcing the evidence of the necessity of a shared physician-patient decision as recommended by many.

\footnotetext{
Marc Scherlinger, ${ }^{1,2,3}$ Thierry Schaeverbeke ${ }^{1,2}$

'Service de Rhumatologie, Centre Hospitalier Universitaire de Bordeaux, Bordeaux, France

${ }^{2}$ Université de Bordeaux, Bordeaux, France

${ }^{3}$ UMR-CNRS 5164 Immunoconcept, Bordeaux, France
}

Correspondence to Dr Marc Scherlinger, Service de Rhumatologie, Centre Hospitalier Universitaire de Bordeaux, Bordeaux 33076, France; marc.scherlinger@chu-bordeaux.fr

Handling editor Josef S Smolen

Contributors MS and TS contributed equally to writing this correspondence.

Funding The authors have not declared a specific grant for this research from any funding agency in the public, commercial or not-for-profit sectors.

Competing interests None declared.

Patient consent Not required.

Provenance and peer review Not commissioned; internally peer reviewed.

(c) Author(s) (or their employer(s)) 2020. No commercial re-use. See rights and permissions. Published by BMJ.

\section{Check for updates}

To cite Scherlinger M, Schaeverbeke T. Ann Rheum Dis 2020;79:e36.

Received 12 December 2018

Accepted 15 December 2018

Published Online First 4 January 2019

\section{(S) Linked}

http://dx.doi.org/10.1136/annrheumdis-2018-214952

Ann Rheum Dis 2020:79:e36. doi:10.1136/annrheumdis-2018-214908

\section{REFERENCES}

1 Glintborg B, Loft AG, Omerovic E, et al. To switch or not to switch: results of a nationwide guideline of mandatory switching from originator to biosimilar etanercept. one-year treatment outcomes in 2061 patients with inflammatory arthritis from the DANBIO registry. Ann Rheum Dis 2019;77:192-200.

2 Cantini F, Benucci M. Switching from the bio-originators to biosimilar: is it premature to recommend this procedure? Ann Rheum Dis 2019;78:e3.

3 Scherlinger M, Schaeverbeke T. Response to: 'Switching from the bio-originators to biosimilar: is it premature to recommend this procedure?' by Cantini and Benucci. Ann Rheum Dis 2019;78:e4.

4 Cantini F, Benucci M. Response to: 'Seeing the glass either half full or half empty: response to the correspondence 'Switching from the bio-originators to biosimilar: is it premature to recommend this procedure?" by Scherlinger and Schaeverbeke. Ann Rheum Dis 2019;78:e25.

5 Scherlinger M, Schaeverbeke T. Additional response to the correspondence: 'Switching from the bio-originators to biosimilar: is it premature to recommend this procedure?' by Cantini and Bennuci. Ann Rheum Dis 2019;78:e25.

6 Schaeverbeke T, Pham T, Richez C, et al. Biosimilars: An opportunity. Position statement of the French Rheumatology Society (SFR) and Inflammatory Rheumatic Disease Club (CRI). Joint Bone Spine 2018:85:399-402.

7 Kay J, Schoels MM, Dörner T, et al. Consensus-based recommendations for the use of biosimilars to treat rheumatological diseases. Ann Rheum Dis 2018;77:165-74.

8 Cohen JD, Tropé S, Munos A. Biosimilars: complements and comments on the recent statement of the SFR and CRI. Comment on: "Biosimilars: an opportunity. Position statement of the French Rheumatology Society (SFR) and Inflammatory Rheumatic Disease Club (CRI)." Schaeverbeke et al. Joint Bone Spine 2018;95:399-402.

9 Scherlinger M, Langlois E, Germain V, et al. Acceptance rate and sociological factors involved in the switch from originator to biosimilar etanercept (SB4). Semin Arthritis Rheum 2018.

10 Tweehuysen L, Huiskes VJB, van den Bemt BJF, et al. Open-label, non-mandatory transitioning from originator etanercept to biosimilar SB4. Arthritis Rheumatol 2018;70:1408-18.

11 Kravvariti E, Kitas GD, Mitsikostas DD, et al. Nocebos in rheumatology: emerging concepts and their implications for clinical practice. Nat Rev Rheumatol 2018; 14:727-40. 